\title{
The genus Ramboldia (Lecanoraceae): a new species, key and notes
}

\author{
Gintaras KANTVILAS \& John A. ELIX
}

\begin{abstract}
The new species Ramboldia blastidiata Kantvilas \& Elix, from Tasmania and mainland Australia is described, and the new combination, R. elabens (Fr.) Kantvilas \& Elix is proposed. The South American $R$. petraeoides var. concava (Müll. Arg.) Fryday is considered a synonym of $R$. petraeoides (Nyl. ex C. Bab. \& Mitt.) Kantvilas \& Elix s. str., and $R$. crassithallina Kalb and $R$. sorediata Kalb, both previously considered endemic to Western Australia, are recorded from Tasmania for the first time. A key to the 11 species of Ramboldia is presented.
\end{abstract}

Key words: Australia, blastidia, lichens, Pyrrhospora, Ramboldia, Tasmania

\section{Introduction}

The genus Ramboldia was introduced by Kantvilas \& Elix (1994) to accommodate crustose lichens with a green, trebouxioid photobiont, lecideine apothecia, an internally unpigmented excipulum composed of radiating, branched and anastomosing hyphae, asci of the Lecanora-type with an amyloid tholus and broadly diverging masse axiale, sparsely branched and anastomosing paraphyses, and simple, hyaline, nonhalonate ascospores. Species of the genus are lignicolous, saxicolous or corticolous; one species is lichenicolous. Ramboldia is very closely related to Pyrrhospora Körb. with which it shares an identical ascus structure and ascospore size and shape (Kantvilas \& Elix 1994; Hafellner 1993). The two genera appear to differ solely by the presence of $\mathrm{K}+$ crimson or purple anthraquinone pigments in the apothecia of the latter (Elix \& Kantvilas 2005). Other genera that can be compared to Ramboldia include Miriquidica Hertel \& Rambold, Lecidella Körb.,

G. Kantvilas: Tasmanian Herbarium, Private Bag 4, Hobart, Tasmania, Australia 7001. Email: gintaras.kantvilas@tmag.tas.gov.au

J. A. Elix: Chemistry Department, The Faculties, Australian National University, Canberra, A.C.T., Australia 0200.
Carbonea (Hertel) Hertel and the Lecanora symmicta (Ach.) Ach. group, all of which differ from Ramboldia chiefly by their ascus structure. In Miriquidica, the masse axiale is relatively poorly differentiated; in Lecidella, it has a \pm rounded apex and does not fully penetrate the tholus, whereas in Carbonea and Lecanora symmicta, it is \pm cylindrical with parallel (rather than divergent) flanks. Carbonea differs further by its opaque, carbonized excipulum. It remains to be seen how the distinction between these genera and the placement of individual species will stand up to scrutiny using DNA sequence data.

The genus initially included five taxa: the Australasian $R$. brunneocarpa Kantvilas \& Elix, R. plicatula (Müll. Arg.) Kantvilas \& Elix, R. stuartii (Hampe) Kantvilas \& Elix and $R$. subnexa (Stirt.) Kantvilas \& Elix, and the widespread $R$. petraeoides (Nyl. ex C. Bab. \& Mitt.) Kantvilas \& Elix, which is known from Australasia, southern South America, South Africa and the Mediterranean.

Subsequently three further Australian species were described: $R$. crassithallina Kalb and R. sorediata Kalb (Kalb 2001), and $R$. farinosa Kalb (Kalb 2004), whereas Hafellner \& Türk (1995) introduced the new combination $R$. insidiosa (Th. Fr.) 
Hafellner for a parasitic lichen that infects Lecanora varia (Hoffm.) Ach. in Europe. South American populations of $R$. petraeoides were recognized as a distinct variety, $R$. petraeoioides var. concava (Müll. Arg.) Fryday by Fryday (2002). The genus clearly attains its greatest species richness in temperate Australasia where open Eucalyptus-dominated woodlands, with an abundance of decorticated, dead wood and exposed rock outcrops, provide a wide range of ideal habitats. In this paper, we provide a key to the 11 species currently recognized, describe a further new species from Australia and Tasmania, and give additional information for several other species.

\section{Material and Methods}

The study is based on material in CANB and HO, collected mostly by the authors, and on selected material and exsiccata from other herbaria as indicated in the text. Specimens were examined using light microscopy. Anatomical features were studied on handcut sections mounted in water, $10 \% \mathrm{KOH}$ and Lugol's Iodine solution after pretreatment with $\mathrm{KOH}$. Chemical analyses were performed using standard methods of thin-layer chromatography (Elix \& Ernst-Russell 1993) and high performance liquid chromatography (Elix et al. 2003).

\section{Key to the species of Ramboldia}

1 Thallus not sorediate, smooth, verruculose to papillate .......... 2

Thallus sorediate or blastidiate . . . . . . . . . . . . . . 9

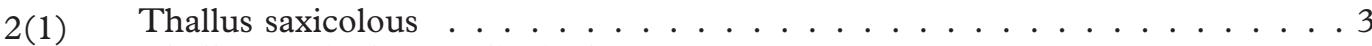

Thallus corticolous or lignicolous . . . . . . . . . . . . . . 4

3(2) Containing norstictic acid, detectable by the formation of needle-like, red crystals after the addition of $\mathrm{KOH}$ to squash preparations of sections of the apothecia or thallus; Southern Hemisphere and the Mediterranean . . . R. petraeoides

Containing baeomycesic and squamatic $( \pm$ ) acids (thallus and apothecia $\mathrm{K}-$ ); mainland Australia and Tasmania . . . . . . . . . . . R. plicatula

4(2) Lichenicolous on the thallus of Lecanora varia; Europe . . . . . . R. insidiosa

Thallus corticolous or lignicolous, not parasitising other lichens . . . . . . . 5

5(4) Apothecia reddish brown; containing norstictic acid ( $\mathrm{K}+\mathrm{red}$; crystals); mainland Australia and Tasmania .............. R. brunneocarpa

Apothecia black; norstictic acid not present . . . . . . . . . . . 6

6(5) Thallus \pm absent or endophloeodal; hypothamnolic acid present, detectable by the $\mathrm{K}+$ purple reaction of crystals in the subhypothecium; mainland Australia, Tasmania and New Zealand ............... R. stuartii

Thallus comprising contiguous or scattered, pale grey to yellowish grey areoles; lacking hypothamnolic acid but containing thamnolic or fumarprotocetraric acids . . . . . . . . . . . . . . . . 7

7(8) Containing thamnolic acid (thallus and subhypothecium $\mathrm{K}+$ yellow); mainland Australia and Tasmania ................... 8

Containing atranorin and fumarprotocetraric acid; cool temperate Northern

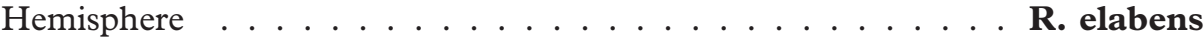

8(7) Areoles plane to convex, mostly $<0.2 \mathrm{~mm}$ wide; paraphyses irregularly swollen to $5 \mu \mathrm{m}$ thick and containing oil inclusions; alpine in mainland Australia and Tasmania . . . . . . . . . . . . . . . . R. subnexa

Areoles convex to bullate, mostly $0 \cdot 2-0.5 \mathrm{~mm}$ wide; paraphyses slender, mostly $1 \cdot 5-2 \mu \mathrm{m}$ thick, lacking oil inclusions; lowland in mainland Australia and Tasmania . . . . . . . . . . . . . R. crassithallina 
9(1) Thallus brownish; apothecia reddish brown; containing norstictic acid (K+ red; crystals); occurring mostly on rock and only rarely on wood; mainland Australia and Tasmania . . . . . . . . . . . . . . . . R. blastidiata

Thallus pale grey or yellowish grey; apothecia black; containing thamnolic or hypothamnolic acids; occurring invariably on wood or bark . . . . . . . 11

10(9) Thallus UV+ white, $\mathrm{K}-$, containing hypothamnolic acid; mainland Australia . . . . . . . . . . . . . . . . . R. farinosa

Thallus UV,$- \mathrm{K}+$ yellow, containing thamnolic acid; mainland Australia and Tasmania

R. sorediata

\section{Taxonomy}

\section{Ramboldia blastidiata Kantvilas \& Elix sp. nov.}

Ramboldiae petraeoidi (Nyl. ex C. Bab. \& Mitt.) Kantvilas \& Elix similis et item vulgo saxicola, acidum norsticticum continens et apotheciis rufo-brunneis, sed thallo blastidiato, mox grosse granulari sorediato differt.

Typus: Tasmania, Flinders Island, western slopes of Strzelecki Peaks, $40^{\circ} 12^{\prime} \mathrm{S} 148^{\circ} 03^{\prime} \mathrm{E}, 150 \mathrm{~m}$ altitude, on granite boulder in dry sclerophyll forest, 27 December 1997, G. Kantvilas 301/97 (HO-holotypus; $\mathrm{BM}$ - isotypus).

(Fig. 1A)

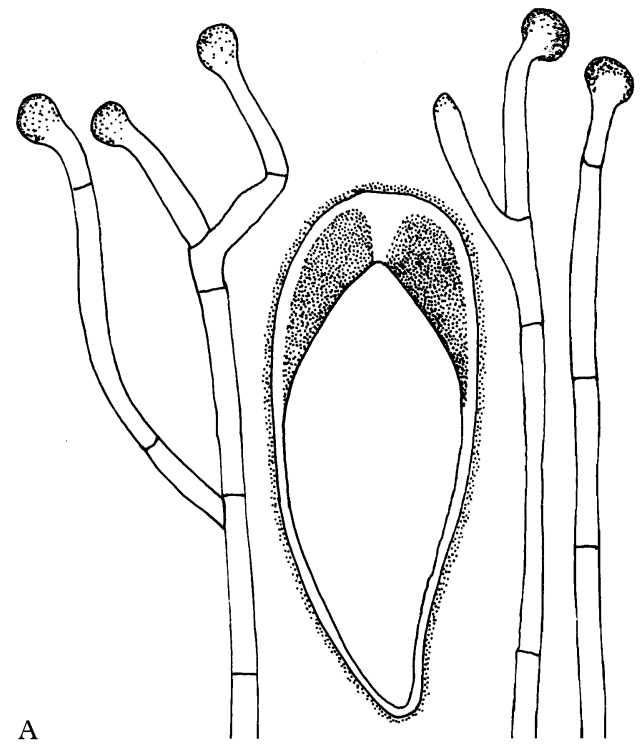

Thallus crustose, forming extensive, irregular, \pm continuous patches to $30 \mathrm{~cm}$ or more wide, pale grey-green, olive-green to dull olive-brown, rimose-areolate at first, with the areoles, plane to convex, c. $0 \cdot 1-$ $0.3 \mathrm{~mm}$ wide and to $c .0 .35 \mathrm{~mm}$ thick, soon becoming blastidiate, abraded and sorediate, and forming a rather coarse, cracked, granular crust to $0.75 \mathrm{~mm}$ thick; soralia pale green to pale fawn-brown, discrete and at first rather punctiform, becoming diffuse; cortex absent; photobiont a unicellular, green, Trebouxia-like alga with cells

FIG. 1. Ramboldia species, portion of hymenium with amyloid parts of asci stippled. A, R. blastidiata (holotype); B, R. elabens (H. Hertel: Lecideaceae Exsiccatae 67). Scale $=20 \mu \mathrm{m}$. 
roundish, 6-18 $\mu \mathrm{m}$ wide. Prothallus not developed but actively growing margins of the thallus sometimes \pm blackened and thickened.

Apothecia lecideine, round to rather irregularly rhomboid, single or sometimes with adjacent ones fused, bright to dull red-brown to dark brown, $0 \cdot 2-1 \mathrm{~mm}$ wide, basally constricted but generally nestled amongst soredia and/or blastidia and appearing rather sunken; margin very thin, concolorous with disc or a little paler, mostly soon excluded; disc plane, undulate to \pm convex, epruinose. Excipulum in section annular, 20-60 $\mu \mathrm{m}$ thick, composed of conglutinated, radiating, branched and anastomosing hyphae $1 \cdot 5-2 \mu \mathrm{m}$ thick, colourless to pale orange, $\mathrm{K}+$ yellow $\rightarrow$ red and developing needle-like red crystals (norstictic acid). Hypothecium colourless, $70-140 \mu \mathrm{m}$ thick, sometimes becoming massive, in the lower part likewise $\mathrm{K}+$ yellow $\rightarrow$ red and developing red crystals. Hymenium 30-45 $\mu \mathrm{m}$ thick, colourless but with a red-brown, $\mathrm{K}+$ olivebrown epithecial layer c. $10 \mu \mathrm{m}$ thick, composed of the pigmented apices of the paraphyses. Asci broadly clavate, 28$40 \times 12-17 \mu \mathrm{m}$, of the Lecanora-type, with well-developed amyloid tholus and a broad, non-amyloid masse axiale with divergent flanks. Paraphyses sparsely branched and anastomosing, separating readily in $\mathrm{KOH}$, (1-) $1 \cdot 5-2 \mu \mathrm{m}$ thick, with apices distinctly capitate, rounded, olive-brown (after the addition of $\mathrm{KOH}), 2-4(-4 \cdot 5) \mu \mathrm{m}$ thick. Ascospores colourless, ellipsoid to fusiformellipsoid, simple but sometimes with a plasma bridge and appearing spuriously septate, $8 \cdot 5-12 \times 3 \cdot 5-5 \cdot 5 \mu \mathrm{m}$.

Pycnidia not located.

Chemistry. Thallus and apothecia containing norstictic and connorstictic acid, easily detected in squash preparations which are $\mathrm{K}+$ yellow $\rightarrow$ red and develop needle-like red crystals.

Remarks. This new species is very closely related to $R$. petraeoides, and anatomically and chemically the two species are identical [see descriptions by Kantvilas \& Elix (1994) and Elix (2004)]. The two taxa differ solely by their thallus: blastidiate-sorediate in $R$. blastidiata and esorediate, smooth, verruculose to \pm papillate in $R$. petraeoides. They frequently occur together and the morphological distinction between the two is clearly evident; also in such cases, the apothecia of the former may frequently be a little smaller. Fertile material of the new taxon is generally not common, and even where apothecia are abundant, there appear to be few welldeveloped asci with ascospores present. In this respect, material from the Australian mainland is particularly poor, despite the abundance of the species there.

Blastidia as lichen structures were first described by Poelt (1980) for Physcia opuntiella Buschardt \& Poelt [=Agonimia opuntiella (Buschardt \& Poelt) Vězda], but have since been noted in other species. They are globose to clavate, very coarsely granular, vegetative propagules that form by budding in a yeast-like manner from the upper surface of the thallus. The common saxicolous, south-eastern Australasian, coastal lichen Rinodina blastidiata Matzer \& H. Mayrhofer is characterized by blastidia and excellent illustrations of these structures are provided by Matzer \& Mayrhofer (1994). In Ramboldia blastidiata, the blastidia soon become abraded and sorediate, with the soredia being pale green to pale fawn-brown and thus paler in colour than the thallus.

Distribution and ecology. This appears to be a widespread but infrequently collected species in temperate Australia and Tasmania. It is rare on wood but relatively common on rocks in open, rather exposed situations from lowland to alpine altitudes, especially in dry sclerophyll vegetation. Although most collections are from Devonian granite and Triassic sandstone, it has been recorded from other rock types as well, including Precambrian metamorphosed sediments, Ordovician conglomerate and Jurassic dolerite. It is typically part of a very species-rich community of saxicolous lichens including $R$. petraeoides, Lecanora farinacea Fée, species of Rhizocarpon and Buellia, and Xanthoparmelia mougeotina 
(Nyl.) D.J. Galloway. In Tasmania, its thallus is sometimes host to an undescribed species of Rimularia (G. Kantvilas \& J. A. Elix unpublished). It is noteworthy that $R$. blastidiata is markedly less common and has a much narrower geographical distribution than its non-sorediate relative, $R$. petraeoides.

Selected specimens examined. Australia: Tasmania: Track to Mt Cameron, $40^{\circ} 59^{\prime} \mathrm{S} 147^{\circ} 56^{\prime} \mathrm{E}, 300 \mathrm{~m}$ alt., 1995, G. Kantvilas 38/95 (HO); c. $2 \mathrm{~km} \mathrm{~W}$ of Long Point, $42^{\circ} 20^{\prime} \mathrm{S} 147^{\circ} 48^{\prime} \mathrm{E}, 305 \mathrm{~m}$ alt., 2006, $G$. Kantvilas 15/06 (HO); summit of Mt Pearse, $41^{\circ} 30^{\prime} \mathrm{S}$ $145^{\circ} 37^{\prime} \mathrm{E}, 1000 \mathrm{~m}$ alt., 2006, G. Kantvilas 104/06 (HO); Tanina Bluff, $42^{\circ} 39^{\prime} \mathrm{S} 147^{\circ} 02^{\prime} \mathrm{E}, 890 \mathrm{~m}$ alt., 2005, G. Kantvilas 209/05 (HO); Mt Murray, $42^{\circ} 28^{\prime}$ S $147^{\circ} 59^{\prime} \mathrm{E}, 315 \mathrm{~m}$ alt., 2006, G. Kantvilas 179/06 (HO); Mt Campbell, 41 $39^{\circ} \mathrm{S} 145^{\circ} 59^{\prime} \mathrm{E}, 1972, G$. C. Bratt 72/1227 (HO); summit of Black Bluff, $41^{\circ} 27^{\prime} \mathrm{S}$ $145^{\circ} 57^{\prime} \mathrm{E}, 1330 \mathrm{~m}$ alt., 2000, G. Kantvilas 146/00 (HO); summit of Mt Maurice, $41^{\circ} 18^{\prime} \mathrm{S} 147^{\circ} 35^{\prime} \mathrm{E}$, $1120 \mathrm{~m}$ alt., 2001, G. Kantvilas 608/81 (HO); Cape Hauy, $43^{\circ} 09^{\prime} \mathrm{S} 148^{\circ} 00^{\prime} \mathrm{E}, 110 \mathrm{~m}$ alt., 2006, G. Kantvilas 342/06 \& P. D. Crittenden (HO). New South Wales: Track to Snowball, Tallaganda State Forest, $35^{\circ} 57^{\prime} \mathrm{S} 149^{\circ} 35^{\prime} \mathrm{E}, 880 \mathrm{~m}$ alt., 1998, H. Streimann 60306 (B, CANB); Dilgry Circle Road, Barrington Tops State Forest, $31^{\circ} 52^{\prime} \mathrm{S} 151^{\circ} 31^{\prime} \mathrm{E}, 1240 \mathrm{~m}$ alt., 1990, f. A. Elix 24921 (CANB); Hanging Mountain, $36^{\circ} 01^{\prime} \mathrm{S} 149^{\circ} 52^{\prime} \mathrm{E}, 700 \mathrm{~m}$ alt., 1989 , H. Streimann 42562A (CANB); Rutherfords Creek, $11 \mathrm{~km} \mathrm{SE} \mathrm{of}$ Nimmitabel, $36^{\circ} 34^{\prime} \mathrm{S} 149^{\circ} 36^{\prime} \mathrm{E}, 850 \mathrm{~m}$ alt., 1994, $\mathcal{F}$. A. Elix 40861 \& K. Kalb (CANB); Blue Mtns, Evans Lookout on trail to Grand Canyon, $33^{\circ} 39^{\prime} \mathrm{S}$ $150^{\circ} 20^{\prime} \mathrm{E}, 1060 \mathrm{~m}$ alt., 2002, G. Kantvilas 176/02 (HO); c. $6 \mathrm{~km} \mathrm{SW}$ of Ebor, $30^{\circ} 27^{\prime} \mathrm{S} 152^{\circ} 19^{\prime} \mathrm{E}$, $1350 \mathrm{~m}$ alt., 2002, G. Kantvilas 520/02 (HO); Molonglo River Falls, $2 \mathrm{~km} \mathrm{~S}$ of Captains Flat, $35^{\circ} 37^{\prime} \mathrm{S}$ $149^{\circ} 27^{\prime} \mathrm{E}, 870 \mathrm{~m}$ alt. (on wood), 1993, 7. A. Elix 30040 (CANB, HO). Australian Capital Territory: Bruce Ridge, $35^{\circ} 15^{\prime} \mathrm{S} 149^{\circ} 05^{\prime} \mathrm{E}, 640 \mathrm{~m}$ alt., 1990, f. A. Elix 25067 (CANB). Queensland: Boolimba Bluff, $25^{\circ} 03^{\prime} \mathrm{S}$ $148^{\circ} 14^{\prime} \mathrm{E}, 580 \mathrm{~m}$ alt., 1993, H. Streimann 52137A (CANB, ESS). South Australia: Kangaroo Island, Waterfall Creek, $35^{\circ} 42^{\prime} \mathrm{S} 136^{\circ} 54^{\prime} \mathrm{E}, 140 \mathrm{~m}$ alt., 1994 , H. Streimann 54949 (CANB). Western Australia: Stirling Range, trail to Toolbrunup Peak, $34^{\circ} 23^{\prime} \mathrm{S} 118^{\circ} 03^{\prime} \mathrm{E}$, $700 \mathrm{~m}$ alt. (on wood), 1994, f. A. Elix 41452 (CANB, $\mathrm{HO})$; Stirling Range, Bluff Knoll, $34^{\circ} 23^{\prime} \mathrm{S} 118^{\circ} 15^{\prime} \mathrm{E}$, c. $1000 \mathrm{~m}$ alt., 1986, G. Rambold 5414 (H. Hertel: Lecideaceae Exsciccatae Nr 195) (HO); Sullivan Rock, $32^{\circ} 23^{\prime} \mathrm{S} 116^{\circ} 15^{\prime} \mathrm{E}, 320 \mathrm{~m}$ alt., 1994, F. A. Elix 40866, H. T. Lumbsch $\mathcal{E}$ H. Streimann (CANB, HO, PERTH).

\section{Ramboldia elabens (Fr.) Kantvilas \& Elix comb. nov.}

Lecidea elabens Fr., Vet. Akad. Handl. 1822: 256 (1822).-Pyrrhospora elabens (Fr.) Hafellner, Herzogia 9: 731 (1993); type not seen.
(Fig. 1B)

For a full description, see Ryan et al. (2004). The chemical composition of this species comprises atranorin (major), fumarprotocetraric acid (major), chloroatranorin (minor), protocetraric acid (minor), confumarprotocetraric acid (minor), succinprotocetraric acid (trace) and an unknown depside (minor). With its areolate thallus and glossy, black apothecia, $R$. elabens displays all the typical features for Ramboldia (see above) as well as having an epihymenium that gives the distinctive $\mathrm{K}+$ olive reaction, seen in the other species of the genus. Its habitat, on dead wood, is also typical. The placement of this distinctive taxon in Pyrrhospora has always seemed somewhat enigmatic, given that it lacks any anthraquinone pigments. Research underway by Dr K. Kalb and co-workers indicates that Pyrrhospora as currently defined is heterogeneous and further supports the placement of $P$. elabens in Ramboldia. Ramboldia elabens is widespread in cool temperate areas of the Northern Hemisphere including Europe, North America and Japan (Hafellner 1993). Records of this species from Australia (e.g. Weber \& Wetmore 1972 ) refer to $R$. subnexa and $R$. stuartii.

Specimens examined. Austria: Ostalpen, Hohe Tauern, Salzburg, zwischen Weißsee und Grünsee oberhalb Enzinger Boden, c. 1900 m alt., 1974, K. Kalb (Plantae Graecenses, Lich. 7) (CANB); Kärnten, Gurktaler Alpen, Nockgebiet, St. Oswald, $46^{\circ} 50^{\prime} \mathrm{N}$, $13^{\circ} 46^{\prime} \mathrm{E}, 1400 \mathrm{~m}$ alt., 1996, R. Türk 21312 (W. Obermayer: Lichenotheca Graecensis, Fasc. 4, no. 74) (CANB).-Finland: Kuusamo, Koillismaa, Mt Konttainen, $66^{\circ} 13^{\prime} \mathrm{N} 29^{\circ} 13^{\prime} \mathrm{E}, 300 \mathrm{~m}$ alt., 7 vii 1981 , L. E. Muhr (H. Hertel: Lecideaceae Exsiccatae 67) (CANB, HO).-United States of America: Maine, Lubec, July 1893, C. E. Cummings \& E. A. Teller (CANB).

\section{Ramboldia petraeoides (Nyl. ex C. Bab. \& Mitt.) Kantvilas \& Elix}

Bryologist 97: 298 (1994).-Lecidea petraeoides Nyl. ex C. Bab. \& Mitt., in J. D. Hooker, Fl. Tasman. 2: 352, tab. CC. fig. D (1859); type: Tasmania, St Patricks River, R. C. Gunn (BM!-holotype; H-isotype).

Ramboldia petraeoides var. concava (Müll. Arg.) Fryday, Mycotaxon 82: 423 (2002).-Lecidea concava 
Müll. Arg., Nuovo Giorn. Bot. Ital. 21: 45 (1889); type not seen.

Fryday (2002) considered South American populations of $R$. petraeoides to be sufficiently distinct from Australasian material to warrant recognition at infra-specific rank. Comparison of a large number of specimens (from Australia, Tasmania and New Zealand) with some collections from South America (Falkland Islands) suggests that they cannot be separated. Sessile, innate, concave to flat apothecia that characterize var. concava are also found in Australasian specimens, albeit uncommonly, especially those from exposed alpine habitats, and represent a continuum of variation in this common, widespread and highly variable lichen. Other characteristics noted by Fryday (2002), such as the pale thallus, reduced exciple, distinctly capitate paraphyses and somewhat broadly elliposid ascospores, are also found consistently in $R$. petraeoides $\mathrm{s}$. str.

Specimens examined. Falkland Islands: Weddell Island, $1100 \mathrm{ft}$ alt., 1968, H. A. Imshaug $41973 \mathcal{E} R$. C. Harris (HO, MSC); West Falklands, summit of Fox Bay Mt, $1008 \mathrm{ft}$ alt., 1968, H. A. Imshaug 42154 E R. C. Harris (HO, MSC).

\section{New Records}

\section{Ramboldia crassithallina Kalb}

Bibliotheca Lichenologica 78: 160 (2001); type: Australia, Western Australia, Gorge Rock, c. $24 \mathrm{~km} \mathrm{SE}$ of Corrigin, $32^{\circ} 25^{\prime} \mathrm{S} 118^{\circ} 00^{\prime} \mathrm{E}$, alt. $300 \mathrm{~m}$, on decorticated twigs of shrubs in depressions of a huge granitic boulder, 18 August 1994, K. \& A. Kalb s.n. (CANB!holotype; hb Kalb-isotype).

Full descriptions of this species are provided by Kalb (2001) and Elix (2004). It is characterized by having an areolate-bullate, grey to pale yellowish grey thallus containing thamnolic acid (thallus and sub-apothecial tissues $\mathrm{K}+$ intense yellow), glossy black apothecia and slender paraphyses [2-3 $\mu \mathrm{m}$ thick according to Kalb (2001) but only $1 \cdot 5-2 \mu \mathrm{m}$ in the Tasmanian specimen]. This species is closely related to $R$. subnexa, which likewise contains thamnolic acid but differs in having plane and not bullate areoles and distinctive, irregularly swollen (to $5 \mu \mathrm{m}$ ) oil paraphyses. The two lichens differ further in their ecology: $R$. crassithallina is a species of dry, lowland habitats whereas $R$. subnexa is a subalpine to alpine species. The single Tasmanian specimen of the former contains barbatic acid in addition to thamnolic acid.

Ramboldia crassithallina was previously known only from Western Australia. In Tasmania, it has been recorded in littoral, scrubby vegetation, just above the spray zone, where it grew on dead wood (of probably Myoporum insulare $\mathrm{R}$. Br.) associated with Xanthoria ligulata (Körb.) P. James, Rinodina australiensis Müll. Arg., Flavoparmelia rutidota (Hook.f. \& Taylor) Hale and species of Opegrapha and Physcia.

Specimen examined. Australia: Tasmania: Flinders Island, Cave Beach, $40^{\circ} 01^{\prime} \mathrm{S} 147^{\circ} 53^{\prime} \mathrm{E}, 5 \mathrm{~m}$ alt., 2006, G. Kantvilas 83/06 (HO).

\section{Ramboldia sorediata Kalb}

Bibliotheca Lichenologica 78: 161 (2001); type: Australia, Western Australia, Yilliminning Rock, c. $12 \mathrm{~km} \mathrm{E}$ of Narrogin, $32^{\circ} 50^{\prime} \mathrm{S} 117^{\circ} 23^{\prime} \mathrm{E}$, altitude $350 \mathrm{~m}$, on decorticated twigs of shrubs growing in depressions of a huge granitic boulder, 16 August 1994, $K$. \& $A$. Kalb s.n. (CANB!-holotype; hb Kalb, $\mathrm{HO}$ !-isotypes).

Full descriptions of this species are provided by Kalb (2001) and Elix (2004). Together with $R$. crassithallina and $R$. subnexa, it is one of three species of Ramboldia that contain thamnolic acid, easily detected in squash preparations by the intense $\mathrm{K}+$ yellow reaction of the subhypothecial and thalline tissues. Ramboldia sorediata is distinguished from these two species by having a sorediate thallus. Although Kalb (2001) suggests that it may be the sorediate counterpart of $R$. subnexa, its slender paraphyses (rather than irregularly thickened oil paraphyses) and ecology would indicate that it is the sorediate counterpart of $R$. crassithallina.

The type collection of $R$. sorediata has an areolate thallus with discrete, rounded, greygreen to somewhat bluish green soralia that gradually spread across the whole thallus. In that respect, the Tasmanian specimens differ 
in that their thallus is composed of contiguous, coarse, ecorticate granules c. $0 \cdot 1-$ $0.25 \mathrm{~mm}$ wide that dissolve into coarse, pale grey-green soredia. However, scattered small areoles are also present, and so this morphological disparity is not considered significant, especially given the few specimens available for study. Another superficially similar species is $R$. farinosa, which has a finely sorediate, whitish thallus and contains hypothamnolic acid (Kalb 2004).

Previously this species was known only from Western Australia. In Tasmania, it has been collected in eucalypt forest where it grew on the cut stumps of eucalypts and on decomposing, decorticated logs. Associated species include Micarea aff. melanobola (Nyl.) Coppins, M. intersociella (Stirt.) Coppins, Lecanora symmicta (Ach.) Ach. aggr., $R$. stuartii and species of Caloplaca and Buellia.

Selected specimens examined. Australia: Tasmania: West of Tahune Bridge, Big Coupe in the Warra SST, $43^{\circ} 06^{\prime} \mathrm{S} 146^{\circ} 41^{\prime} \mathrm{E}, 120 \mathrm{~m}$ alt., 2006, G. Kantvilas 213/06 (HO); $2 \mathrm{~km} \mathrm{~W} \mathrm{of} \mathrm{New} \mathrm{Norfolk} \mathrm{along}$ Glenora Road, $42^{\circ} 47^{\prime} \mathrm{S} 147^{\circ} 02^{\prime} \mathrm{E}, 90 \mathrm{~m}$ alt., 1997, $G$. Kantvilas 59/97 (HO).

We acknowledge with thanks the speedy provision of critical loan material by Dr Klaus Kalb (Neumarkt) and Dr Christine Cargill (Canberra). Dr Jean Jarman prepared the drawing for publication.

\section{REFERENCES}

Elix, J. A. (2004) Ramboldia. Flora of Australia 56A (Lichens 4): 63-68.

Elix, J. A. \& Ernst-Russell, K.D. (1993) A Catalogue of Standardized Thin Layer Chromatographic Data and
Biosynthetic Relationships for Lichen Substances, 2nd Edn. Canberra: Australian National University.

Elix, J. A., Giralt, M. \& Wardlaw, J. H. (2003) New chloro-depsides from the lichen Dimelaena radiata. Bibliotheca Lichenologica 86: 1-7.

Elix, J. A. \& Kantvilas, G. (2005) A new species of Pyrrhospora (Lecanoraceae, lichenized Ascomycota) from Australia, with notes on Pyrrhospora laeta. Australasian Lichenology 57: 6-11.

Fryday, A. M. (2002) New combinations and records of lichenized-fungi from southern South America. Mycotaxon 82: 421-428.

Hafellner, J. (1993) Die Gattung Pyrrhospora in Europa. Herzogia 9: 725-747.

Hafellner, J. \& Türk, R. (1995) Über Funde lichenicoler Pilze und Flechten im Nationalpark Hohe Tauern (Kärntner Anteil, Österreich). Carinthia II 185/105: 599-635.

Kalb, K. (2001) New or otherwise interesting lichens. Bibliotheca Lichenologica 78: 141-167.

Kalb, K. (2004) New or interesting lichens II. Bibliotheca Lichenologica 88: 301-329.

Kantvilas, G. \& Elix, J. A. (1994) Ramboldia, a new genus in the lichen family Lecanoraceae. Bryologist 97: 296-304.

Matzer, M. \& Mayrhofer, H. (1994) The saxicolous Rinodina teichophila and three closely related species from the Southern Hemisphere (Physciaceae, lichenized Ascomycetes). Acta Botanica Fennica 150: 109-120.

Poelt, J. (1980) Physcia opuntiella spec. nov. und die Lebensform der Sprossenden Flechten. Flora 169: 23-31.

Ryan, B. D., Tønsberg, T., Nash, T. H. \& Hafellner, J. (2004) Pyrrhospora. In Lichen Flora of the Greater Sonoran Desert Region. Volume 2 (T. H. Nash III, B. D. Ryan, P. Diederich, C. Gries \& F. Bungartz, eds): 436-439. Tempe: Lichens Unlimited.

Weber, W. A. \& Wetmore, C. M. (1972) Catalogue of the lichens of Australia, exclusive of Tasmania. Beihefte zur Nova Hedwigia 41: 1-137. 